RFP-2945

July 19,1980
RFP-2945

July 19,1980

\title{
FLUIDIZED BED INCINERATION PROCESS \\ DESIGN FOR TRANSURANIC WASTE
}

Andrew J. Johnson

F. Graham Meyer

David L. Anderson

Burke A. Bell

Pen K. Feng

Manager: D. L. Ziegler

Program Manager: L. L. Richey

Chemistry Research and Development

PILOT PLANT DEVELOPMENT

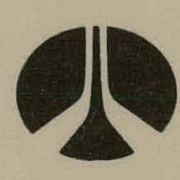

Rockwell International

Energy Systems Group

Rocky Flats Plant

P.O. Box 464

Golden, Colorado 80401

U. S. DEPARTMENT OF ENERGY

CONTRACT DE-AC04-76DPO3533 


\section{DISCLAIMER}

This report was prepared as an account of work sponsored by an agency of the United States Government. Neither the United States Government nor any agency Thereof, nor any of their employees, makes any warranty, express or implied, or assumes any legal liability or responsibility for the accuracy, completeness, or usefulness of any information, apparatus, product, or process disclosed, or represents that its use would not infringe privately owned rights. Reference herein to any specific commercial product, process, or service by trade name, trademark, manufacturer, or otherwise does not necessarily constitute or imply its endorsement, recommendation, or favoring by the United States Government or any agency thereof. The views and opinions of authors expressed herein do not necessarily state or reflect those of the United States Government or any agency thereof. 


\section{DISCLAIMER}

Portions of this document may be illegible in electronic image products. Images are produced from the best available original document. 
This report was prepared as an account of work sponsored by an agency of the United States Government. Neither the United States Government nor any agency thereof, nor any of their employees, makes any warranty, express or implied, or assumes any legal liability or responsibility for the accuracy, completeness, or usefulness of any information, apparatus, product, or process disclosed, or represents that its use would not infringe privately owned rights. Reference herein to any specific commercial product, process, or service by trade name, trademark, manufacturer, or otherwise, does not necessarily constitute or imply its endorsement, recommendation, or favoring by the United States Government or any agency thereof. The views and opinions of authors expressed herein do not necessarily state or reflect those of the United States Government or any agency thereof.

\footnotetext{
Printed in the United States of America Available from the National Technical Information Service U.S. Department of Commerce Springfield, Virginia 22161

Page Range

001-025

026-050

051-075

076-100

*All microfiche are priced at $\$ 3.50$

Prices Subject to Change Without Notice

Domestic Price*

$\$ 5.00$

6.00

7.00

8.00

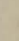


Printed

July 19,1980
RFP-2945

UC-70 NUCLEAR

WASTE MANAGEMENT

TIC-4500 (Rev. 68)

\title{
FLUIDIZED BED INCINERATION PROCESS \\ DESIGN FOR TRANSURANIC WASTE
}

\author{
Andrew J. Johnson \\ F. Graham Meyer \\ David L. Anderson \\ Burke A. Bell \\ Pen K. Feng \\ Manager: D. L. Ziegler \\ Program Manager: L. L. Richey \\ Chemistry Research and Development \\ PILOT PLANT DEVELOPMENT
}

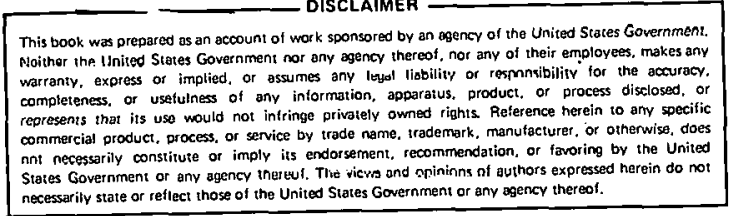

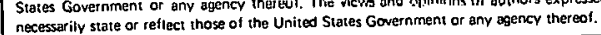

SUBJECT DESCRIPTORS

Fluidized Bed

Incinerators

Transuranic Waste

Waste Management

\footnotetext{
ROCKHELL INTERNATIONAL

ENERGY SYSTEMS GROUP

ROCKY FLATS PLANT

POST OFFICE BOX 464

GOLDEN, COLORADO 80401
}

Prepared under Contract DE-AC.04-76DP03533

for the

Albuquerque Operations office

U.S. Department of Energy 
RFP-2945 


\section{ONTENTS}

Abstract.......................................... 1

Introduction........................................ 1

Summary ........................................... 2

Process Description.................................... 2

Design Basis........................................ 5

Process Equipment.................................... 6

Waste Preparation Equipment.......................... 6

Bed Material Addition System.......................... 7

Feed screw...................................... 7

Primary Fluidized Bed and Primary Cyclone................. 7

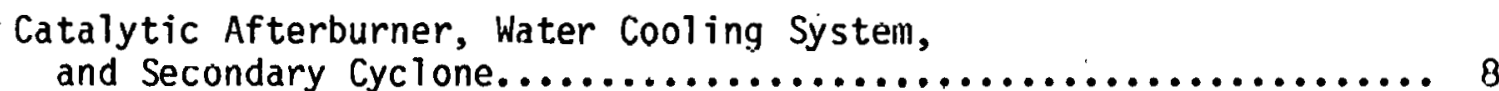

Sintered Metal Filters and Heat Exchanger................... 10

Process $\mathrm{Blowers} . \ldots \ldots \ldots \ldots \ldots \ldots \ldots \ldots \ldots \ldots \ldots \ldots \ldots \ldots \ldots \ldots \ldots \ldots$

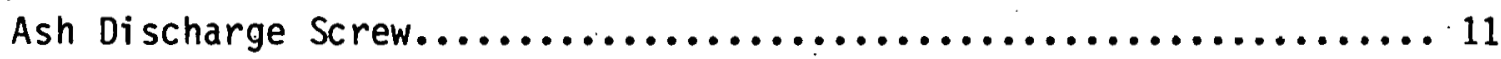

Preheat systems................................... 12

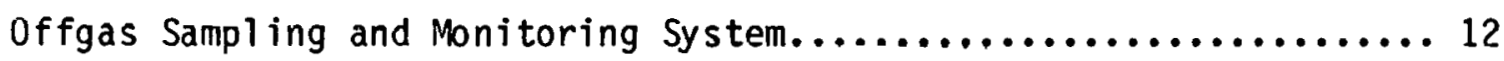

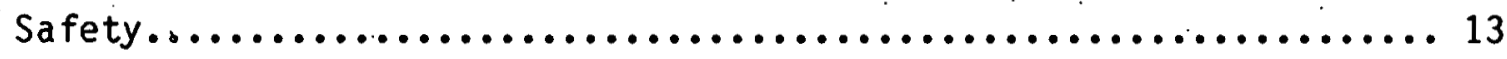

Data Acquisition System................................ 14

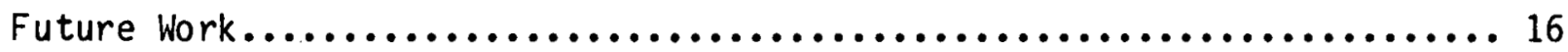

Conclusions........................................ 16 
RFP -2945 


\section{FLUIDIZED BED INCINERATION PROCESS DESIGN FOR TRANSURANIC WASTE}

Andrew J. Johnson, F. Graham Meyer, David L. Anderson, Burke A. Be11, and Pen K. Feng

Abstract. A fluidized bed incineration facility has been installed at the Rocky Flats Plant to develop and demonstrate a process for the combustion of transuranic waste. The unit's capacity is about $82 \mathrm{~kg} / \mathrm{hr}$ of combustible solid waste, which is nine times higher than the rate for the operating pilot-scale unit. The facility utilizes nonaqueous, in situ neutralization of acid gases. These gases are generated during the combustion of halogen-containing materials. The low-temperature $\left(550^{\circ} \mathrm{C}\right)$ operation el iminates refractory-l ined equipment.

\section{INTRODUCTION}

Fluidized bed incineration of transuranic (TRU) combustible waste is undergoing development and evaluation at the Rocky Flats Plant (RFP).* Based upon data obtained from a $9 \mathrm{~kg} / \mathrm{hr}(20 \mathrm{lb} / \mathrm{hr})$ pilot plant, an $82 \mathrm{~kg} / \mathrm{hr}(180 \mathrm{~Tb} / \mathrm{hr})$ demonstration fluidized unit was constructed and became operational in 1978. Research and development on the fluidized incineration concept has progressed continually since 1971, and some significant advantages of this process

ॠD. L. Ziegler, A. J. Johnson, and L. J. Meile, "Fluidized Bed Incineration of Radioactive Wastes," Transactions of the ANS 1973 Winter Meeting, San Francisco, California, November 11-15, 1973. over conventional incineration have been demonstrated.

For a number of years, conventional incineration has been used at RFP for combustion of radioactive waste containing recoverable amounts of plutonium. This approach has been effective; however, major problems have been encountered. Maintenance requirements have been high because of equipment corrosion, short refractory life, and mechanical problems. Incineration temperatures have been difficult to control and sometimes have reached $1000{ }^{\circ} \mathrm{C}$, resulting in a high-temperature plutonium oxide that has been difficult to dissolve in the Plant's aqueous recovery system. An aqueous flue-gas scrubbing system has been employed, producing an additional stream of liquid waste.

The fluidized bed concept offered substantial advantages toward minimizing the problem areas just mentioned. It provided in situ neutralization of acid gases by the sodium carbonate $\left(\mathrm{Na}_{2} \mathrm{CO}_{3}\right)$ bed medium when materials such as polyvinyl chloride (PVC) were burned. A fluidized bed catalytic afterburner provided efficient, low-temperature, and nonflaming combustion of the offgas. These benefits eliminated the need of refractory lining and aqueous flue gas scrubbing with its associated waste stream. The equipment corrosion rate also was reduced. Generally, equipment life was prolonged, maintenance reduced, and better flexibility and control of process conditions were achieved. 


\section{SUMMARY}

This report details the concept, processing steps, and equipment items for using a fluidized bed incinerator (FBI) to incinerate transuraniccontaminated combustible waste.

The concepts of this system incorporate (1) nonaqueous in situ neutralization of acidic gases, (2) starved oxygen combustion in a primary fluidized bed, (3) combustion of the flue gas in the secondary fluidized bed, (4) lowtemperature operation $\left(550^{\circ} \mathrm{C}\right)$ throughout the system to eliminate the need for refractory linings, (5) negativepressure operation for contamination control, and (6) an advanced, computerbased, data acquisition and control system for optimum operation. The facility design is based on an operating pilot-scale system and represents a scale-up factor of nine based on solid waste feed rates, and a scale-up factor of 6.3 based on kilojoule-per-hour heat release rates. The process includes waste-container introduction, size reduction, classification of combustibles from noncombustibles, waste feeding, starved oxygen combustion, flue gas after burning, product collection, and offgas cleaning. About $45 \%$ of the heat of combustion will be extracted through the walls of the catalytic afterburner by a water spray cooling system. The remaining heat will be removed by a flue gas heat exchanger downstream from the afterburner. Motive force and negative pressure control for the process are provided by high-speed exhaust blowers downstream of the flue gas heat exchangers.

\section{PROCESS DESCRIPTION}

The fluidized bed incineration process is essentially the same for both the $9 \mathrm{~kg} / \mathrm{hr}$ pilot unit (Figure 1) and the $82 \mathrm{~kg} / \mathrm{hr}$ demonstration unit (Figure 2).
For both units, process equipment is located within a canyon separated from the control area by containment walls, which isolate the probable contamination area. While many operational functions can be performed through gloves mounted in the pilot plant containment wall, the differing scale of equipment for the demonstration unit made this operational mode impractical. Operating conditions on the large unit, e.g., temperature, flow, and pressure drops, are on computer readout, with adjustments made remotely by operating personnel in the computer room.

The waste, in $0.2 \mathrm{~m}^{3}$ (55-gallon) drums, is discharged into a receivingsorting glove box. There the waste is hand-sorted to remove large-size tramp metal as it is fed into the primary shredder. An air classifier, mounted below the shredder, conveys lighter combustible waste to a second-stage shredder while heavier metal objects drop into the glove box where tramp metal is collected. An adjustable damper mechanism on the waste classifier controls the air flow rate. Second-stage, shredded waste drops directly into the feed screw hopper. A bridge-breaking device placed at the middle of the hopper aids in a uniform distribution of waste into the feedscrew flights.

The adjustable-speed feed screw conducts the waste into the center of the primary bed. Inside the primary reactor, a bed of heated sodium carbonate granules is fluidized by a mixed stream of air and nitrogen. Enough heat is released by partial combustion to maintain a bed temperature of approximately $550{ }^{\circ} \mathrm{C}$ and to pyrolyze the remainder of the waste. Acid gases (e.g., $\mathrm{HCl}$ from thermal decomposition of PVC) are neutralized immediately by the $\mathrm{Na}_{2} \mathrm{CO}_{3}$ to form a stable sodium salt ( $\mathrm{NaCl}$ ), carbon 


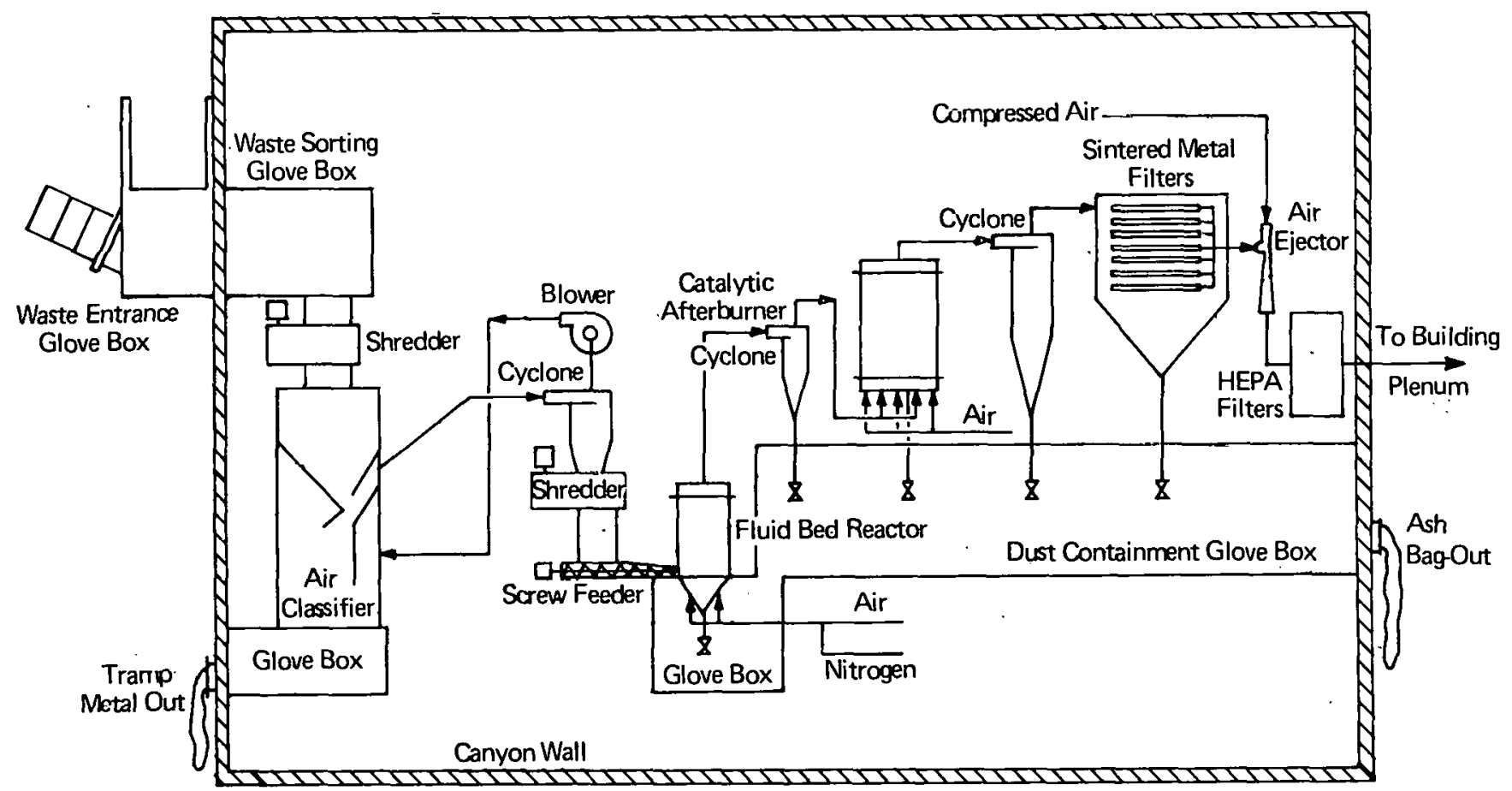

FIGURE 1. Fluidized Bed Incineration Pilot Unit $(9 \mathrm{~kg} / \mathrm{hr})$

dioxide $\left(\mathrm{CO}_{2}\right)$, and water vapor $\left(\mathrm{H}_{2} \mathrm{O}\right)$. The fluidizing gas flow can be kept constant while the air-nitrogen ratio is varied. This enables the unit to cope with any variation in heat content of the waste being fed, while holding constant the flow velocity necessary for good fluidization. Hydrocarbon-rich flue gas from the primary reactor passes through a cyclone collector where entrained $\mathrm{Na}_{2} \mathrm{CO}_{3}, \mathrm{NaCl}$, and flyash are removed before the flue gas enters the fluidized bed catalytic afterburner. Combustibles in the flue gas are burned in the bed of hot chromiaalumina catalyst where a separate stream of air is introduced for combustion under excess oxygen conditions. A portion of the combustion heat is removed by cooling water sprayed on the lower section of the afterburner. Low-quality steam from the sealed cooling chamber flows into a reflux condenser, and the water is then returned to the chamber.

Flue gas leaving the secondary reactor contains flyash, catalyst dust, and small amounts of $\mathrm{NaCl}$ and $\mathrm{Na}_{2} \mathrm{CO}_{3}$ carried over from the primary reactor. This gas stream passes through another cyclone collector, and then through parallel banks of sintered metal filters. The gas is cooled to $50{ }^{\circ} \mathrm{C}$ by a water-cooled heat exchanger before being pulled through the blowers. Discharge is through a bank of high efficiency particulate air (HEPA) filters. It then passes through four more stages of HEPA filtration in the building plenum system before being released to the outside atmosphere. offgas analyzers monitor the effluent stream of combustion products to measure combustion efficiency. 
RFP -2945

FIGURE 2. Flow Diagram of Fluidized Bed Incineration System ( $82 \mathrm{~kg} / \mathrm{hr}$ Demonstration Unit) for Transuranic Waste
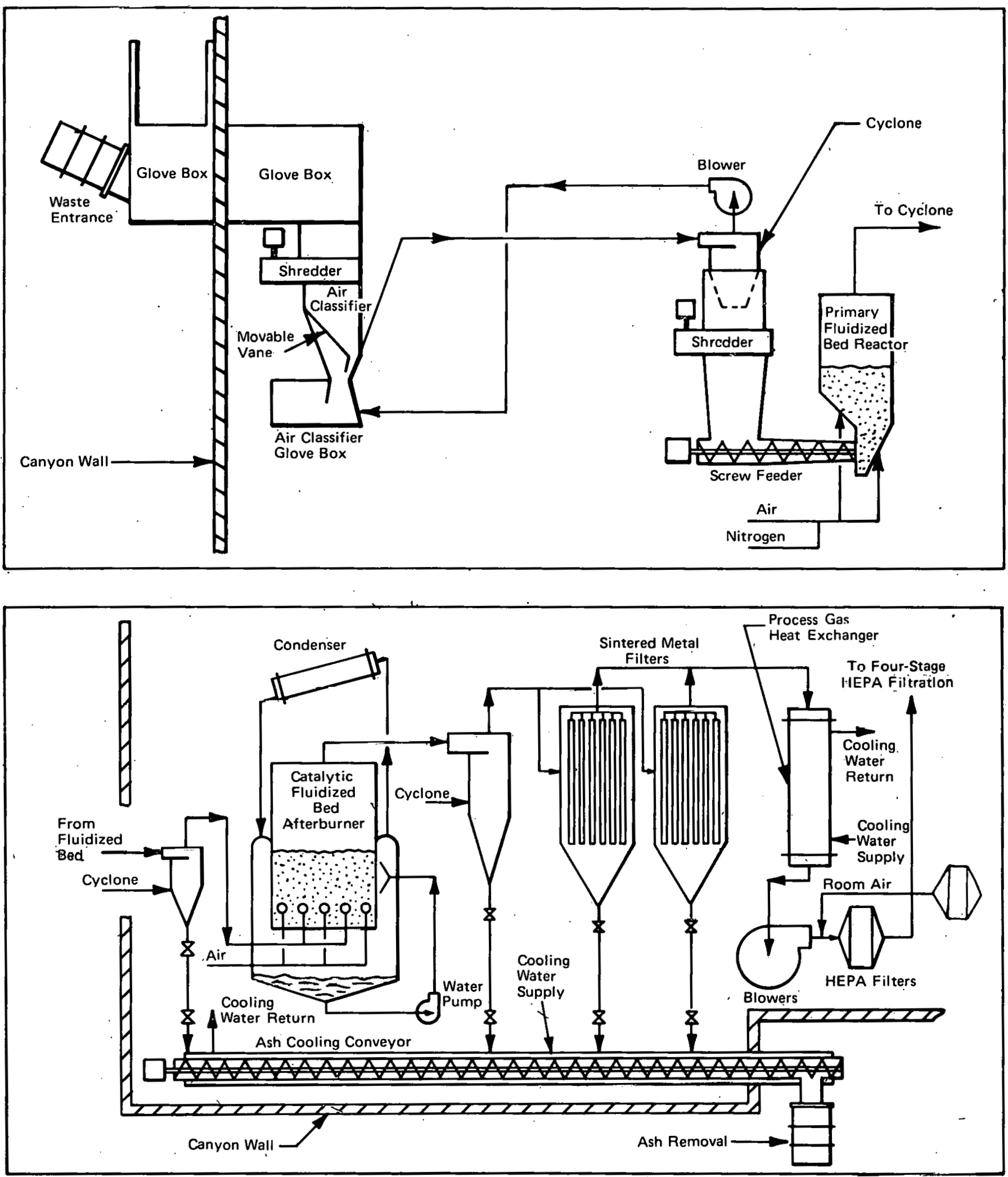
Residue of the combustion process is collected from three points: the primary cyclone, secondary cyclone, and the sintered metal filter hoppers. All three collectors discharge into one water-cooled screw conveyor that cools the hot residue before it is discharged into a receiving drum. The conveyor line penetrates the canyon wall; the receiving drum is located in an adjacent air-lock room.

\section{DESIGN BASIS}

Major factors involved in the decision on proper scale-up parameters for the demonstration unit and the basis of design are summarized as follows:

1. Cost - How to achieve the project objective of a demonstrated working, fluidized bed incineration system without exceeding the budgeting constraint.

2. Space Limitations - The process was to be located within an existing building; consequently, there was a fixed, maximum, physical area that could accommodate process equipment, an adequate facility for storage, and operating personnel without compromising safety and environmental concerns.

3. Waste Considerations - The availability of a sufficient amount of TRU waste as feed material and guaranteed proper disposal of end products.

4. Plant Utilities - The availability of sufficient amounts of necessities such as air, nitrogen, electrical power, and cooling water.
5. Engineering - Scale-up factors with which the engineering staff could reliably perform the design work involved.

All of these factors played a part in the final selection of nine as a scale-up factor. This value, then, became the scale-up factor in feed rate for the demonstration unit compared to the pilot unit. At the $82 \mathrm{~kg} / \mathrm{hr}$ rate, there was confidence in proper engineering design, based upon results from pilot plant process data, without violating the budgetary, space, waste, and Plant utilities constraints.

A survey was made of Plant production areas to determine the average composition of TRU combustible waste that was being generated. From the survey results (see Table 1), an averate heat content of $19,500 \mathrm{~kJ} / \mathrm{kg}(8,400 \mathrm{Btu} / \mathrm{lb})$ was calculated for the combustible portion; this value was used in sizing the FBI for the $82 \mathrm{~kg} / \mathrm{hr}$ throughput that was desired.

TABLE 1. Average Composition of Rocky Flats TRU Combustible Waste

\begin{tabular}{lcc}
\multicolumn{1}{c}{ Componont } & Weight Percent. \\
Latex & 23.1 \\
Paper & 44.0 \\
Polyvinyl chloride & 3.6 \\
Polyurethane & 0.5 \\
Polyethylene & 4.1 \\
Cloth & 5.9 \\
Leather & 0.5 \\
Wood & 6.7 \\
Water & 4.6 \\
Tramp metal & & 7.0 \\
& Total & 100.0 \\
\hline
\end{tabular}

Other pertinent design information is shown in Tables 2-7. Fluidization 
velocities, calculated for an empty bed, are based on data taken from a large number of pilot plant runs. Velocities are held at a level giving good bed mixing and at the same time holding down particle entrainment. For the primary reactor, an average bed temperature of $550{ }^{\circ} \mathrm{C}$ is maintained for rapid decomposition of combustibles. Operating temperatures above $600{ }^{\circ} \mathrm{C}$ are avoided because of the possible formations of a $\mathrm{NaCl}$ $\mathrm{Na}_{2} \mathrm{CO}_{3}$ eutectic that melts in the $615^{\circ} \mathrm{C}$ temperature range. The operating temperature of the catalytic afterburner reflects the range at which the catalyst is effective without high-temperature damage to the vessel.

\section{PROCESS EQUIPMENT}

This section describes waste preparation equipment, the bed material addition system, feed screw, primary fluidized bed and primary cyclone, catalytic afterburner, water cooling system, secondary cyclone, sintered metal filters, heat exchanger, process blowers, ash discharge screw, preheat systems, offgas sampling and monitoring system, safety considerations of design, and the data acquisition system.

Waste Preparation Equipment

Waste preparation equipment includes the Remote Weighing Station, waste drum hoist, waste-sorting glove box, coarse shredder, air classifier, tramp-metal glove box, air-classifier cyclone, fine shredder, and bridge breaker. All combustible solid waste received in drums will be processed through the waste preparation equipment in the following manner.

The identification number of the waste drum is entered via the Remote Weighing
Station (part of the data acquisition system) and checked by the computer. If the identification number is not found on the programmed list of waste drums to be processed, the waste drum is rejected. However, if the identification is matched, the Remote Weighing Station provides a net weight of the corresponding waste drum, which is recorded by the computer.

The waste-drum hoist lifts the drum to the waste-sorting glove box, which is divided into two areas: waste receiving and hand-sorting. The waste drum is tilted and mated to the waste-receiving area of the glove box, where the bagged waste is pulled from the drum into the receiving area. The glove box is equipped with two interconnected guillotine doors that form an air lock to separate the receiving and hand-sorting areas and provide ventilation control. The first guillotine door is lifted, and the bagged waste is pulled into the airlock section. The first door is then closed, the second guillotine door is opened, and the waste is pulled into the sorting area of the glove box. The receiving area of the glove box is also equipped with a door that is sized to handle HEPA filters.

After the waste has been hand-sorted to separate combustibles and large noncombustibles, the combustibles are fed to a Saturn Model 3630 Shredder. Both shredders (coarse and fine) are counterrotating, dual, horizontal shaft cutters that operate in the low-revolutionsper-minute range with hydraulic drives powered by 30-hp motors.

The shredded waste falls into a Rockwell-designed air classifier equipped with a 5-hp fan. The air stream, which is regulated by a movable vane in the air classifier, separates light and dense particles. The vane also can be retracted to a position to remove any 
plugs formed above the air classifier. The dense particles fall into the tramp-metal glove box while the lighter particles are conveyed from the air classifier in the air stream. The 1 ighter particles (mainly combustibles) are then separated from the air stream by a cyclone. Most of the discharged air from the cyclone is returned to the fan inlet. A portion is exhausted to the waste-sorting glove box, however, for ventilation control. Combustibles collected from the cyclone drop into a second Saturn Mode 13630 Shredder. Waste leaving the second shredder falls into the main feed hopper above the feed screw. This hopper is equipped with a bridge breaker, a paddle wheel driven by a $90^{\circ}$ sweep pneumatic actuator. The bridge breaker maintains a constant feed of waste to the feed screw by eliminating bridging of waste in the main feed hopper.

Waste collected in the tramp-metal glove box is bagged out. Some of the combustible waste left in this material will be hand-segregated and recycled through a connecting stand pipe to the air classifier cyclone inlet duct.

Bed Material Addition System

A pneumatic transport system is used to replenish fluidized bed materials. The weighed sodium carbonate or catalyst is conveyed, as required, to either the primary fluidized bed or the catalytic afterburner.

Feed Screw

Waste feeding into the incinerator is accomplished by a screw feeder to give the continuous uniform feed rate desired.

The feed screw is tapered from $18.4 \mathrm{~cm}$ (7.25 in.) to a $10.8-\mathrm{cm}(4.25-\mathrm{in.})$ diameter at the discharge end. This taper provides a continuous running seal of compressed waste between the feed hopper and the primary fluidized bed. Also, the feed screw can be retracted to mate the tapered metal plug at the discharge end of the screw flight against the screw housing. This provides a method of isolating the feed hopper from the primary reactor during start-up or shutdown. Screw speed is controlled through a 7.5-hp d.c. motor regulated by a Ratiotrol SCR Motor Controller. The screw speed is inversely proportional to an input signal received from a thermocouple located in the bed of the catalytic afterburner. High temperatures within the catalytic afterburner will cause the feed rate of the feed screw to slow down; lower temperatures will speed up the feed rate.

A water cooling jacket is located around the screw barrel at the interface of the barrel with the primary bed. This jacket protects the screw unit from high-temperature effects and premature melting of the feed material.

Primary Fluidized Bed and Primary Cyclone

The waste fed by the screw feeder is pyrolytically combusted in the primary fluidized bed.

Design specifications for the primary bed reactor are shown in Table 2 . The construction material, 316 stainless steel, was selected based on coupon tests conducted in the pilot plant fluidized bed incinerator operating at RFP. The inside diameter of the reactor is $0.9 \mathrm{~m}$ (3 ft) except for the distributor plate section. This conical section is designed so that during operation, any tramp metal introduced into the solid waste stream will migrate to the bottom of the bed. A screw conveyor removes the collected metal while gas flow countercurrent to the 
screw discharge retains less-dense bed material inside the vessel.

Fluidizing gas enters through a series of concentric holes that are partially covered to prevent material backflow through the distributor plate.

TABLE 2. Primary Fluidized Bed Design Parameters

\begin{tabular}{lc} 
Minimum fluidizing velocity $(\mathrm{m} / \mathrm{sec})$ & 0.5 \\
Maximum fluidizing velocity $(\mathrm{m} / \mathrm{sec})$ & 0.7 \\
Solid waste feed rate $(\mathrm{kg} / \mathrm{hr})$ & 82 \\
Bed heat release rate $\left[\mathrm{kJ} /\left(\mathrm{m}^{2} \cdot \mathrm{hr}\right)\right]$ & $6.18 \times 10^{\mathrm{s}}$ \\
Percent of total combustion & 23.7 \\
Unfluidized bed height $(\mathrm{m})$ & 0.7 \\
Initial sodium carbonate size $(\mu \mathrm{m})$ & $500-1000$ \\
\hline
\end{tabular}

Incineration operation begins with an initial loading of $500 \mathrm{~kg}$ of sodium carbonate. A mixture of air-nitrogen fluidizing gas, heated by two, parallel, 80-kW Chromalox Preheaters, heats the bed to $300{ }^{\circ} \mathrm{C}$. Concurrently, the catalytic afterburner is heated to about $425{ }^{\circ} \mathrm{C}$. Feeding of waste can begin when these two temperatures are attained.

TABLE 3. Primary Cyclone Specifications

$\begin{array}{lcc}\text { Cyclone flow (STP) }\left(\mathrm{m}^{3} / \mathrm{sec}\right) & 1.16 \times 10^{-1} & (246 \mathrm{scfm}) \\ \text { Cyclone flow (ATP) }\left(\mathrm{m}^{3} / \mathrm{scc}\right) & 4.85 \times 10^{-1} & (1028 \mathrm{scfm}) \\ \text { Flue gas temperature }\left({ }^{\circ} \mathrm{C}\right) & 550 & \\ \text { Flue gas pressure }(\mathrm{kPa}) & 68.9 & (10 \mathrm{psia}) \\ \text { Cyclonic inlet velocity }(\mathrm{m} / \mathrm{sec}) & 30.5 & (100 \mathrm{ft} / \mathrm{sec}) \\ \text { Collection efficiency }(\mathrm{wt} \%) & 99 & \end{array}$

Incineration is generally conducted at a bed temperature of $500 \pm 50{ }^{\circ} \mathrm{C}$, and is maintained by a temperature controller actuating a pneumatic control valve on the nitrogen inlet line. Total constant gas flow is maintained by an electronic flow controller operating on input of the sum of electronic signals from two mass flow meters. The controller output actuates a pneumatic control valve on the compressed air inlet to the primary bed. Air flow thus complements the nitrogen flow, the total of the two being a constant. Generally, operating temperatures are maintained below $615{ }^{\circ} \mathrm{C}$. This is done to el iminate melting of bed material that could contain a sodium carbonate - sodium chloride eutectic with a melting point of $615{ }^{\circ} \mathrm{C}$.

Thermal decomposition of PVC and other chlorinated hydrocarbons produces hydrogen chloride that is neutralized by the sodium carbonate, forming sodium chloride. A hard shell of sodium chloride forms around the sodium carbonate particle, restricting further reaction within the particle. This shell is abraded away by bed action, freeing the sodium carbonate surface for more reaction. The sodium chloride is then removed from the bed, along with flyash and other small particles, by elutriation with the offgas.

Pyrolytic offgas and entrained particles are exhausted through the primary cyclone. Design specifications for this cyclone are shown in Table 3 . The collected particulate matter is discharged through a double knife gate valve arrangement to the ash-discharge screw.

Catalytic Afterburner, Water Cooling System, and Secondary Cyclone

Hydrocarbons and other gaseous combustibles in the primary bed offgas stream are burned in the fluidized bed 
TABLE 4. Design Specifications for the Catalytie Afterburner

$\begin{array}{lc}\text { Minimum fluidizing velocity }(\mathrm{m} / \mathrm{sec}) & 0.5 \\ \text { Maximum fluidizing velocity }(\mathrm{m} / \mathrm{sec}) & 0.7 \\ \text { Bed heat release rate }\left[\mathrm{kJ} /\left(\mathrm{m}^{2} \cdot \mathrm{hr}\right)\right] & 4.76 \times 10^{\mathrm{s}} \\ \text { Percent of total combustion } & 76.3 \\ \text { Unfluidized bed height }(\mathrm{m}) & 0.5-1.0 \\ \text { Temperature operating range }\left({ }^{\circ} \mathrm{C}\right) & 500 \pm 50 \\ \text { Spray cooler heat removal rate }(\mathrm{kJ} / \mathrm{hr}) & 7.2 \times 10^{\mathrm{s}}\end{array}$

catalytic afterburner. Design specifications for the catalytic afterburner are shown in Table 4.

The flue yas stream exiting the primary cyclone is split. It is then added to each end of the recirculating flue gas distributor, which provides part of the fluidizing gas for the catalyst. The remainder of the fluidizing gas is the combustion air injected by a Rockwel1design single-stage jet ejector into perforated pipes at the bottom of the vessel. The design basis for the flue gas distributor was obtained from experimental runs with the FBI pilot plant. The design eliminated hole-plugging by particles in the flue gas stream.

The initial catalyst charge, $2000 \mathrm{~kg}$ of chromic oxide on alumina, is pneumatically transferred into the vessel. During the run, new catalyst is added through the same system to replace that lost by attrition. There are two fluidizing air preheating systems for the afterburner: (1) a $90-\mathrm{kW}$ Chromalox Preheater and (2) a methanol-fueled system utilizing catalytic combustion. Initially only the Chromalox Preheater. is used to bring the fluidizing air to $300^{\circ} \mathrm{C}$. The methanol catalytic combustor is located after the Chromalox Preheater on the fluidizing air stream; the flow to the catalytic combustor is regulated by a flow control loop. After the air stream reaches $300{ }^{\circ} \mathrm{C}$, the controller activates a pump to feed methanol to the catalytic combustor (a platinum catalyst on a ceramic honeycomb). Once the afterburner bed has reached $200{ }^{\circ} \mathrm{C}$, the methanol flow is switched to the primary cyclone. The vaporized methanol is conveyed through the flue gas distributor piping and is mixed with the fluidizing air in the afterburner; the methanol is now combusted directly in the afterburner. After a bed operating temperature of $500 \pm 50^{\circ} \mathrm{C}$ is attained, all preheating equipment is shut of $f$, and the waste feed is started. The waste feed rate is regulated so there are sufficient hydrocarbons in the offgas streain to maintain operating temperature in the afterburner.

About $45 \%$ of the process heat will be removed by a water cooling system. The water cooling system, completely enclosing the base of the afterburner, is a series of 10 full-cone spray nozzles. To continuously recycle water to the spray nozzles, the cooling system is equipped with a shell and tube condenser. Table 5 contains design specifications for the condenser.

TABLE 5. Design Specifications for the Cooling Water Condenser

$\begin{array}{ll}\text { Material of construction } & \text { carbon steel } \\ \begin{array}{l}\text { Heat removed rate }(\mathrm{kJ} / \mathrm{hr}) \\ \quad(680,000 \mathrm{Btu} / \mathrm{hr})\end{array} & 7.20 \times 10^{5} \\ \begin{array}{l}\text { Number of passes } \\ \text { Tube number }\end{array} & 1 \\ \begin{array}{l}\text { Water feed rate range }\left(\mathrm{m}^{3} / \mathrm{sec}\right) \\ \quad(20.225 \mathrm{gpm})-(220 \mathrm{gpm})\end{array} & 1.99 \\ \begin{array}{l}\text { Shell outlet temperature range }\left({ }^{\circ} \mathrm{C}\right) \\ \text { Operating pressure }(\mathrm{kPa})\end{array} & \mathrm{S}-75^{\circ} \mathrm{C} \\ \quad(11.80 \text { psia) }\end{array}$


A temperature control loop will regulate the afterburner temperature at an approximately constant value. A thermocouple measures the bed temperature and, if higher than the set point $\left(\sim 550^{\circ} \mathrm{C}\right)$, the output of the controller on the feed screw will be decreased. Conversely, if the bed temperature is lower than the set point, the output will be increased to provide additional feed and, consequently, additional combustible flue gas. Speed on the feed screw is regulated by a Ratiotrol SCR Motor Controller. By this method of process control, operating temperature of the afterburner can be maintained by increasing or decreasing the speed of the feed screw.

Exit flue gas contains flyash, catalyst dust, and small concentrations of sodium carbonate and sodium chloride. About 75 to $80 \%$ of this particulate matter will be removed from the flue gas by the secondary cyclone. Design specifications for the secondary cyclone are shown in Table 6 . The collected particulate will be discharged through a double knife gate valve arrangement to the ash discharge screw.

TABLE 6. Design Specifications for the Secondary Cyclone

\begin{tabular}{|c|c|c|}
\hline Cyclone flow (STP) $\left(\mathrm{m}^{\mathrm{s}} / \mathrm{scc}\right)$ & 0.33 & $(688 \mathrm{scfm})$ \\
\hline Cyclone flow (ATP) $\left(\mathrm{m}^{3} / \mathrm{sec}\right)$ & 1.5 & $(3248 \mathrm{acfm})$ \\
\hline Flue gas temperature $\left({ }^{\circ} \mathrm{C}\right)$ & 550 & \\
\hline Flue gas pressure $(\mathrm{kPa})$ & 61.0 & (8.85 psia) \\
\hline Cyclone inlet velocity $\left(\mathrm{m}^{3} / \mathrm{sec}\right)$ & 30.5 & $(100 \mathrm{ft} / \mathrm{sec})$ \\
\hline $\begin{array}{l}\text { Collection efficiency (wt \%) } \\
\text { (Particle size }>8 \mu \mathrm{m})\end{array}$ & 99.9 & \\
\hline
\end{tabular}

Sintered Metal Filters and Heat Exchanger

Particulate matter that is not removed from the afterburner offgas stream by the secondary cyclone will be collected by the sintered metal filtiers.

There are two filter housings, each with 96 sintered metal filters, to handle fine particulate matter that has not been removed by the primary and secondary cyclones. Each filter tube is one inch in diameter, approximately four feet long, and constructed of Inconel. The tubes are arranged in 11 rows with each row having its own blow-back header (90 psig air). Each blow-back header has a low temperature service solenoid valve to control the duration of the blow-back pulse. IA operation, each blow-back header will pulse its associated filter tubes every 22 minutes. The design face velocity for the filters at operating temperatures is $0.091 \mathrm{~m} / \mathrm{sec}$ $(18 \mathrm{ft} / \mathrm{min})$. In operation, this face velocity has been found to be too high. Current plans call for redesigning this equipment to reduce the face velocity to about $0.025 \mathrm{~m} / \mathrm{sec}(5 \mathrm{ft} / \mathrm{min})$.

Particulate matter cleaned from the filters collects at the bottom of the sintered metal filter chambers. This material flows through two knife gate valves to an ash screw conveyor.

A water-cooled, fin-tube heat exchanger is used to cool process offgas leaving the sintered metal filters. Table 7 lists the pertinent design data. Initial data from 1 imited amounts of incineration indicate acceptable performance.

During operation, the cooling water flow rate is kept at a maximum to preclude high offgas temperatures, which are caused by upset conditions, from 
TABLE 7. Process Offgas Heat Exchanger

\begin{tabular}{|c|c|c|}
\hline Direction of fluid flow & countèrcurrent & \\
\hline Design gas flow rate $\left(\mathrm{m}^{3} / \mathrm{sec}\right)$ & 0.35 & (750 scfm) \\
\hline Inlet gas temperature $\left({ }^{\circ} \mathrm{C}\right)$ & 550 & \\
\hline Outlet gas temperature $\left({ }^{\circ} \mathrm{C}\right)$ & 40 & \\
\hline Inlet $\mathrm{H}_{2} \mathrm{O}$ temperature $\left({ }^{\circ} \mathrm{C}\right)$ & 20 & \\
\hline $\begin{array}{c}\text { Maximum outlet } \mathrm{H}_{2} \mathrm{O} \\
\text { temperature }\left({ }^{\circ} \mathrm{C}\right)\end{array}$ & 35 & \\
\hline Maximum $\mathrm{H}_{2} \mathrm{O}$ flow rate $\left(\mathrm{m}^{3} / \mathrm{sec}\right)$ & 0.009 & $(150 \mathrm{gpm})$ \\
\hline Maximum gas pressure drop ( $\mathrm{kPa})$ & 2.5 & $\left(10\right.$ in $\left.\mathrm{H}_{2} \mathrm{O}\right)$ \\
\hline $\begin{array}{l}\text { Heat removal rate at steady } \\
\text { state condition }(\mathrm{kJ} / \mathrm{hr})\end{array}$ & $8.5 \times 10^{5}$ & $(806,000 \mathrm{Btu} / \mathrm{hr}$ \\
\hline Material of construction & $\begin{array}{l}304 \text { stainless } \\
\text { steel }\end{array}$ & \\
\hline
\end{tabular}

blowers below $40{ }^{\circ} \mathrm{C}$ to avoid exceeding exhaust temperature limitations of the aluminum impellers.

Blower vacuum is controlled with two commonly operated butterfly valves on the inlet of each blower series. These valves are set by the pressure differential between the feed screw hopper and the primary fluidized bed. Blower air flow rate is measured with two mass flow meters on the inlet of each blower series. The flow measurement is used to control a pnuematically actuated butterfly valve. This valve vents canyon air into the system to maintain the minimum flow necessary for stable blower operation.

\section{Ash Discharge Screw}

damaging the process blowers and HEPA filters. At the same time, a dew-point analyzer continuously monitors the gas outlet for possible formation of condensation products.

\section{Process Blowers}

The process motive force is the vacuum supplied by four high-speed centrifugal blowers. These blowers are arranged in two parallel sets of two blowers in series with interstage gas coolers. Forty-horsepower, close-coupled motors power the blowers, which individually pull a minimum of $1100 \mathrm{acfm}$ at $40^{\circ} \mathrm{C}$ and 7.4 psia, and have a discharge pressure of 12 psia. The combination of four blowers pull 2150 acfm at $40{ }^{\circ} \mathrm{C}$ and 6.5 psia negative. The interstage coolers maintain the gas inlet temperature of the second-stage
Ash from the two cyclones discharges through double knife gate valves directly into an 8.2-m-long sealed screw conveyor. Ash from the two sintered metal filter hoppers also discharges through double knife gate valves into a similar 2-m-long screw conveyor. This second screw conveyor is arranged perpendicular to and above the long one. Thus, ash conveyed from the sintered metal filters falls by gravity into the longer conveyor and mixes with ash from the cyclones. Both sections of the ash discharge screw are powered by a 1-h.p. motor, gear box, and forward/reverse SCR speed control. The entire ash discharge conveyor system has integral cooling-water coils. This ensures that the ash is cooled from 450 to $35{ }^{\circ} \mathrm{C}$ before it is discharged into the ash-receiving drum, which is situated outside the canyon wall. The ash discharge temperature is continuously monitored with a thermocouple. If the 
ash discharge temperature exceeds a preset level, the screw conveyor system will automatically stop discharging ash and begin rotating in an alternate reverse and forward mode. This action allows additional cooling of the ash to the safe discharge temperature. Outside the canyon wall, the long conveyor screw discharges ash through a motor-driven rotary valve into a lined waste drum. The whole discharge end, with the exception of the drum itself, is contained in a glove box for dust and contamination confinement.

Preheat Systems

Primary Bed:

Two 80-kW heaters in parallel, totaling $576,000 \mathrm{~kJ}(546,080 \mathrm{Btu})$, heat the combustion air/nitrogen mixture during start up. The heaters are thermostatically controlled and are capable of heating $400-\mathrm{scfm}$ air/nitrogen to $340{ }^{\circ} \mathrm{C}$. Combustible waste feed can be started after the bed reaches $300-350{ }^{\circ} \mathrm{C}$. Once waste is being fed, the electrical heaters are turned off.

Afterburner:

A single 90-kW electrical resistance heater, in conjunction with a ceramic honeycomb-platinum catalytic heater, supplies the start-up heat. The electrical heater raises the temperature of the 450-scfm combustion air to a temperature sufficient to operate the catalytic heater. The catalytic heater, burning methanol, then provides the remaining heat necessary to raise the temperature of the catalytic bed to $400-450{ }^{\circ} \mathrm{C}$. After the bed reaches operating temperature, both the electrical resistance and the catalytic heater are shut off.

A diaphragm metering pump supplies methanol to the system from a tank in the catalyst loading room. The stroke of the alcohol pump is continuously varied by means of an electric actuator, which is controlled by the afterburner temperature control loop. Alcohol can be selectively fed either to the catalytic preheater for start-up or to the inlet gas stream to the afterburner. The latter condition is for maintaining bed temperature when offgases from the primary do not have enough heat content to maintain proper bed temperature.

Offgas Sampling and Monitoring System

\section{In-Stack Monitoring:}

Exhaust gas oxygen and moisture content are monitored with two instruments using "in-stack" sensor probes.

An in-line hygrometer monitors the exhaust gas dew-point temperature. The aluminum oxide capacitance probe for this instrument is located in the exhaust duct, immediately downstream of the exhaust gas cooler. The hygrometer measures exhaust gas moisture content by using the relationship between water vapor concentration and the probe capacitance. Instrument readout is via a local meter and the Foxboro/PDP-11 data acquisition system.

An in-line oxygen analyzer monitors oxygen concentration in the exhaust gas. The probe for this instrument is located in the exhaust gas duct immediately upstream from the exhaust gas cooler. This probe operates on a zirconium oxide fuel cell principle with probe voltage being proportional to the difference between oxygen concentration in exhaust gas and the normal atmospheric concentration of oxygen. Instrument readout is also possible via both a local meter and the Foxboro/PDP-11 data acquisition system. 
Offgas Sampling and Instrumentation:

Rockwell International at the Rocky Flats Plant developed an integrated exhaust gas sampling system. This system samples, conditions, and distributes exhaust gas to a total hydrocarbon analyzer and dual carbon monoxide and carbon dioxide analyzer. A provision has also been allowed for a future hydrogen chloride and sulfur dioxide monitor.

The offgas sample system is enclosed in a cabinet adjacent to, but outside, the canyon wall. A sintered metal filter probe, downstream from the exhaust gas cooler, cleans the sample before that sample enters the heater and insulated teflon sample line. The sample pump is a diaphragm type that supplies the various analyzers through a permeation dryer and individual flow meters.

Sample pump vacuum is monitored, and should a preset value be exceeded, the sample line and filter probe are automatically "blown-back" with Plant nitrogen. Analyzer zero calibration gas is aiso automatically supplied by the system, using preset timers. Analyzer return samples are collected by the offgas sample system and returned to the exhaust gas duct downstream from the sample point.

The hydrocarbon analyzer monitors concentrations of exhaust gas hydrocarbon by means of the $f 1$ ame ionization technique. Instrument readout is via a local meter and the Foxboro/PDP-11 data acquisition system.

The carbon monoxide/carbon dioxide analyzer is a dual monitoring, non-dispersive infrared type; both carbon monoxide and carbon dioxide sample concentrations are monitored simul taneously for readout on local meters and the Foxboro/PDP-11 data acquisition system.
Safety

The fluidized bed incineration process has been designed with the utmost detail and attention being given to personnel protection and process safety. All operating personnel are required to carry respirators and to wear protective clothing, which includes coveralls, safety shoes, and safety glasses. Warning signs are posted wherever a hazardous situation may exist. All glove ports are located a safe distance away from moving equipment. Most process equipment is located within the totally enclosed canyon area. This isolates the probable equipment contamination area; personnel usually are not required to enter the canyon during operation. The methanol pump, methanol tank, catalyst, and sodium carbonate feed stations are in a controlled access room within which all equipment is rated for explosion-proof operation. Two hydraulic drive units, which provide power to the shredders and feed screw, are also located in a separate room. This location isolates the noise from operating personnel. Rupture disks are installed on the primary and secondary reactors to protect them from the unlikely event of system pressurization. Self-monitoring alpha detectors and three selective alpha air monitors (SAAMS) continuously sample the air at and near the process area.

Inside the control room, instantaneous process information is monitored by means of an extensive computercontrolled data acquisition and process monitoring system. Al1 major equipment can be turned on and off from a control panel. An intercommunications system provides the communications 1 ink between the control room and operating personnel in the general area. 
Data available for observations consist of 25 temperatures, 16 pressures, 3 flows, 2 weights, 5 analyzer readings (carbon monoxide, carbon dioxide, oxygen, dew point, and hydrocarbon), and one contact closure. In addition, 8 control loops are monitored and their set points and output values are displayed on the cathode ray tube (CRT). Work is in progress to incorporate high/low al arm warning; trend analysis, and automatic shutdown functions into the process monitoring and control system. This system, with direct digital control and supervisory set point capabilities, remains to be fully implemented.

\section{Data Acquisition System}

A sophisticated process monitoring, control, and data evaluation system has been installed for the fluidized bed incinerator. A programmable data processor-11/10 (PDP-11/10)

minicomputer controls the process and analyzes pertinent data. The Foxboro Interspec system is the communications link between the computer and the Foxboro Spec 200 input/output (I/0) modules.

A simplified hardware configuration is shown in Figure 3. In the figure, process measurements are divided into two groups. Those measurements associated with process control are converted to 0 - to $10-V$ signals proportional to the measured value in the Spec 200 input modules. The signals then go to a controller and the Foxboro Interspec Controller Communication Module (CCM) where analog-to-digital signal conversion occurs. Process measurements not associated with cantrol loops are converted to 0 - to $10-V$ signals proportional to the measured value in the Spec 200 input modules. These signals then go to the Foxboro
Interspec Analog Input Modules (AIM) where analog-to-digital signal conversion occurs. All digital signals are then transferred via a serial communications bus to the Foxboro Universal Interspec Communications Module (UISCM) and to the Digital Equipment Corporation (DEC) PDP-11/10 unibus. The signals received by the PDP-11/10 are stored on the Remex Flexible Diskette System, converted to engineering values, and displayed on the cathode ray tube (CRT). Incoming signals also are checked for alarm status and are checked against previously received signals to determine a rate of change for each measurement. In a similar manner, signals generated by the PDP-11/10 for correcting the controlled variables travel via the PDP-11/10 unibus, UISCM, serial communications bus, CCM, Spec 200 output modules, and to the final control devices.

In the control loops, the controllers mode of set point operation in the CCM may be automatic, manual, or computer controlled. With these options, the operator can make adjustments to the control system in the local automatic or manual mode as a backup for computer control.

This incineration process has 8 control loops for the adjustment of critical flows, pressures, and temperatures. In addition, 25 temperatures, 16 pressures, 3 flows, 2 weights, 1 contact closure, and 5 analyzers are monitored. The Foxboro CCM has a capacity of handling 16 control loops, and each Foxboro AIM can receive 48 input signals. The Foxboro Interspec system can therefore accommodate an additional 8 control loops and 44 process measurements with minor hardware additions.

Sofiware for this system is oriented for a real-time computer controlled 
FIGURE 3. Hardware Configuration for Process Monitoridg and Control System

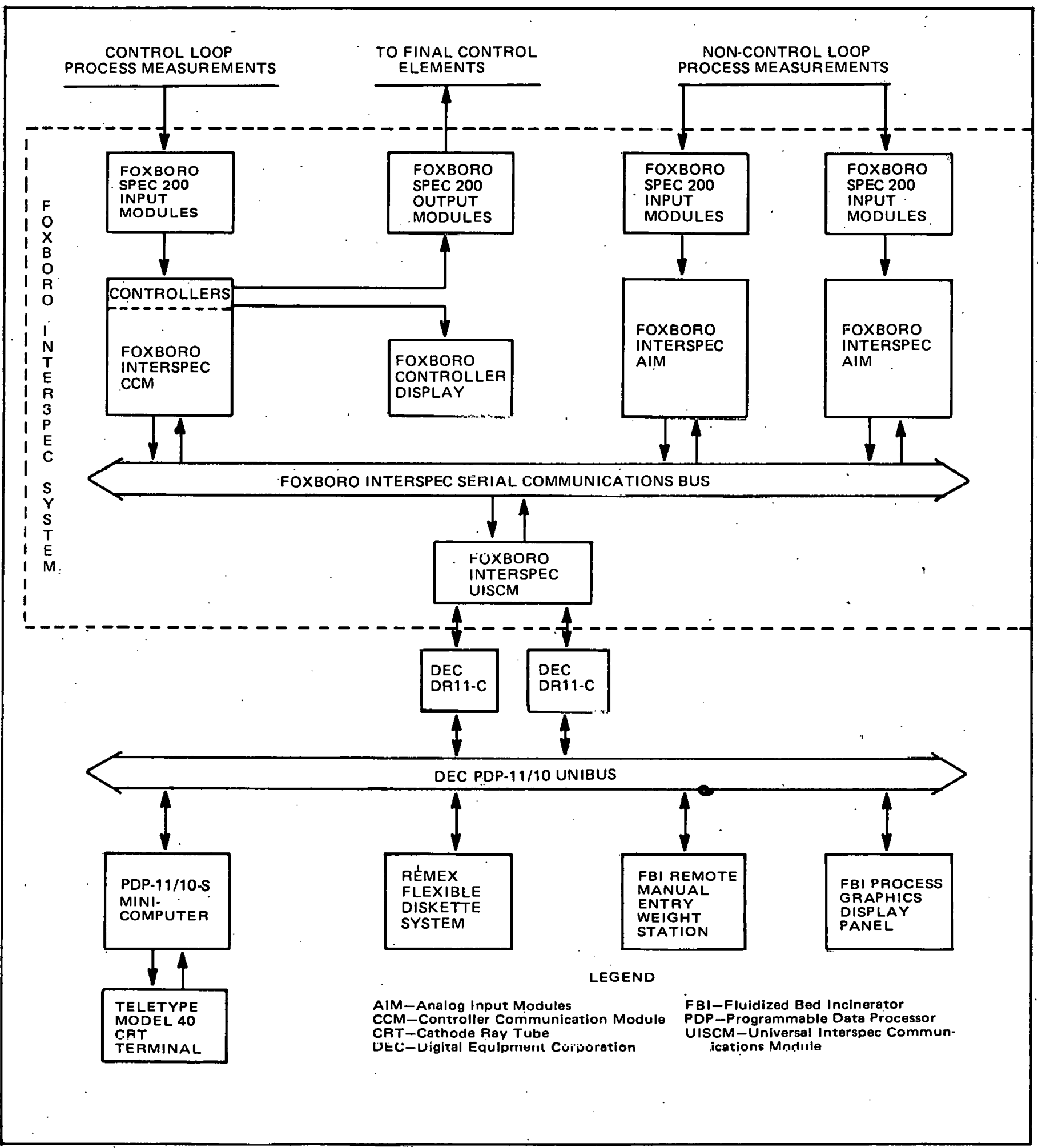


process. The software controls the transfer of all process sensor data into a process data base. Data handling software accesses and transfers information between peripheral devices and the PDP-11/10 minicomputer. Peripheral devices are the Foxboro Interspec system, Remex Flexible Diskette system, CRT terminal, and the Remote Weighing Station (RWS).

All peripheral devices are vendorsupplied items except the RWS. This device is being developed to impose strict inventory control on drums containing radioactivity-contaminated feed material. In the operating sequence for this unit, the RWS will accept a drum identification code from the operator and check it against a master unprocessed drum list. If the drum code is on this list, the RWS will accept the gross weight of the drum as it is hoisted to the entry glove box. A load cell located in the drum-list hoist will acquire the gross weight and transmit this value to the RWS. The RWS, having detected the movement of the load to the entry glove box, will acquire the weight and check for overweight readings. When the load is detected moving down to ground level, the RWS acquires a tare weight and subtracts it from the gross reading to get a net weight. After the operator transmits the processed drum code and associated net weight to the PDP-11/10 minicomputer, the RWS is ready to start this sequence again. As each drum is processed, the drum identification number is removed from the master unprocessed drum list and appended to the processed drum list. Any deviation in this sequence will abort acquisition of the data. The operator must determine the malfunction, correct the error, and re-initiate the operating sequence.

\section{FUTURE , WORK}

Work planned over the next few years is focused on determining optimum operational parameters and increasing the versatility of the unit.

1. After all synthetic solid waste combustion runs have been completed, the demonstration facility will begin and will complete combustion studies on non-line generated solid waste. After all of these waste runs have been finished, a complete process design report will be issued $(F Y-80)$.

2. A liquid feed system will be designed, purchased, installed, and tested with liquid combustible wastes. Experimental runs are scheduled for FY-79 and FY-80. A complete design package for the liquid feed system will be issued in $\mathrm{FY}-80$.

3. A graphic display planned for the data requisition system will be installed in FY-79.

4. Complete design report for RFP line generated waste will be issued in FY-82.

\section{CONCLUSIONS}

The following conclusions are based on the synthetic waste run that was completed in FY-78:

1. Process equipment that has operated successfully according to design is as follows:
a. Waste preparation equipment
b. Feed screw
c. Primary fluidized bed 
d. Secondary fluidized bed

e. Water cooling system on afterburner

f. Electrical preheaters

g. Methanol catalytic combustor

Sufficient data have not been collected to fully evaluate the remainder of the process equipment.
2. The data acquisition system is invaluable in maintaining the accuracy of measurements made by process control and non-control 10ops.

3. From an operational standpoint, the software package for the data acquisition system provides sufficient data to operate the demonstration system from the control room. 
RFP-2945 